To appear in Australian Educational Researcher; available online at: https://doi.org/10.1007/s13384$\underline{020-00384-x}$

\title{
What counts? Inclusion and Diversity in the Senior English Curriculum ${ }^{1}$
}

Lauren Bliss and Alexander Bacalja

The University of Melbourne

\section{Abstract}

This paper reports findings from a research project investigating text-list trends in the Senior Victorian English curriculum between 2010-2019. These lists are historical products, the consequence of ways of thinking about literature and subject-English that are simultaneously inclusive and exclusive. Policy documents emphasise the need for the English curriculum to foster values of 'inclusivity' and 'diversity' of culture and for texts that reflect these values in "constructive" and "affirmative" senses. In order to test the extent to which text-lists associated with subject English address these ambitions, a content analysis of three hundred and sixty texts was conducted, guided by the question: what are the trends in VCE English text lists between 2010 and 2019? Focusing on trends related to text type, story setting, sex/sexuality and Indigenous themes, we found that while some goals of policy documents were met, the lists lacked diversity beyond traditional notions of what constitutes texts worthy of study.

Words: 6286

\section{Introduction}

Ideals that underpin equality and universality in education have been a site of heated public debate throughout Australian history. This has been the case from the earliest period of settlement in the late $18^{\text {th }}$ century, as Austin and Selleck (1975) note in their study of the passionate intensity of public discussion at the time, which they argue to be a measure of the importance attached to universal education in Australian society. However, these discussions

\footnotetext{
${ }^{1}$ Cite as: Bliss, L., \& Bacalja, A. (2020). What counts? Inclusion and diversity in the senior English curriculum. The Australian Educational Researcher, 1-18. doi:https://doi.org/10.1007/s13384$\underline{020-00384-x}$
} 
reflected the need to 'civilise' the population - especially the local convict population - in order to achieve the democratic, rehabilitative aim of the colonial project. In Australia, historical debates and discourses about education were, to a degree, indebted to the European Enlightenment, with its emphasis on individualism, rationality, freedom and democracy. Nonetheless, the realities of Australia as a penal colony meant the perceived value of education was bound up in assumptions that education was addressed to ignorant, disobedient, criminal groups (p. 15). The civilizing assumption was especially present in the authoritarian reality of the classrooms of the period, marked as being restraining, with "primitive rote learning techniques, stern discipline, constricted curriculums and neatly organised timetables" (p. 5) in stark contrast to the Enlightenment's emphasis on individuality and free will. Nonetheless, these contradictions - between the authoritarian reality of the classroom and curriculum, the complexity of original Enlightenment philosophy and its instrumentalised, simplified version in public debate about education - were all directed toward the same future ideal and democratic vision. The hope was that Australia would become a democratic society, and the goal was to ensure 'equal opportunity for all' through education. As expressed by one colonist, this carried with it the noteworthy aim, "to bring within reach of the industrial classes a larger share in the pleasures of knowledge" (p. 321).

How might these contradictions between the stated goals of education and the realities of the classroom inform debates, which have continued up until present day, about universality and democracy in education in contemporary Australia? The stated rationale for the Victorian Senior English curriculum² refers to using texts to support students to "develop a sense of themselves, their world and their place within it" (Victorian Curriculum and Assessment Authority, 2015, p. 5). This is to be achieved through texts that represent a range of forms and that come from the contemporary world, the past, Australia and other cultures. The preamble to the policy guiding the selection of these texts, the Principles, Guidelines and Procedures for Prescribed VCE text lists (Victorian Curriculum and Assessment Authority, 2018), hereafter the VCAA Guidelines, describes

\footnotetext{
${ }^{2}$ In the state of Victoria, all students who wish to complete their senior school certificate are mandated to study one of three English subjects (English, Literature and English Language). This study focuses on the most popular of these subjects, 'VCE English'.
} 
the values that underpin text selection in the Senior English curriculum. Text selection should "support and promote democratic and community values", draw on "traditional and contemporary examples" and "balance challenge and expectation with the needs of the individual" (p. 1) while also ensuring English leads to the development of critical thinking skills and connects with career pathways. Texts must also "reflect excellence" and be exemplary models of genre, style or theme (for example) to be chosen.

There is, within these two documents, an emphasis on the need for the curriculum to foster values of inclusivity and diversity of culture and for texts to reflect these values in "constructive" and "affirmative" senses. However, these two terms, like the notion of "excellence", remain undefined in the document. The curriculum is also required to encompass texts "by or about Australians including Aboriginal and Torres Strait Islander peoples, and the study of texts that reflect Australia's engagement with Asia" (p. 3). These noble policy aims are common to range of curriculum policy documents, from national to state levels including the most recent iteration of the Australian Curriculum which mandates cross-curriculum priorities associated with Aboriginal and Torres Strait Islander Histories and Culture (ACARA, 2019) and the Melbourne Declaration (MCEETYA, 2008).

However, education, as Raymond Williams (1961) points out, is about a set of cultural choices, both conscious and unconscious. Schools, as one element of education systems, including the hidden curriculum they promote (Apple, 1982) preserve and distribute what is perceived to be 'legitimate knowledge', and through this, confer cultural legitimacy on particular groups (Apple, 1979, p. 63). Thus, schools are not limited to role of the distributors of culture, but also take on the task of producing culture. Our study focuses on the aims of text selection policies as they appear, on the surface, largely in step with the values of the wider community. However, the current reality of their implementation within the curriculum requires attention as ideals, such as 'inclusivity' and 'diversity', remain vague and undefined in the documents themselves.

Our focus is on the specific policy aims, outlined in the VCAA guidelines and Study Design Rationale, and the realisation of those aims in senior school text-lists that inform the implementation of the curriculum in the state of Victoria. Our study analyses these policy aims 
in the light of four specific trends and the extent to which these trends reflect aims in terms of the guidelines for texts to be 'inclusive' as well as 'affirming' and 'constructive' in the broadest sense. We analyse trends in text-types (i.e. film, poetry, novels), trends in text-setting (place and time) and engagement with world literature, trends in representation of sex and sexuality and trends in the Indigenous authorship and the representation of Indigeneity and colonisation. Through analysing the trends as they appear across the text-lists, our study responds to the question: to what extent are the principles and imperatives found in policy documents associated with the Senior English Curriculum reflected in the texts listed for study? In the state of Victoria, there has been little empirical research to determine the extent to which diverse voices and stories have been included for literary study.

\section{The importance of texts in subject English}

While canonical literature continues to be prevalent and valued in Victoria, as elsewhere, concerns that literacy standards are declining, as well as political misgivings over the mixing of high and low culture have left conservative commentators concerned that the canon is under attack and that the importance of Western literature must be re-established (Devine, 2005; Donnelly, 2018). Debates about the literature validated by these text-lists are a proxy for debates about English itself, and resonate with other recent cultural wars playing out in the education space, (see the Literacy Wars (Snyder, 2008), the reading wars (Pearson, 2004), and the history wars (Clark, 2008)).

As scholars have suggested, to understand English, and move beyond popular rhetoric espoused by conservative political elements, requires placing the subject within its historical and social context (Green \& Beavis, 1996). Rather than conceiving of English as a unitary and unifying subject, it is more accurate to think of English in a plural sense. This means it is often complex and contradictory and crafted to meet the imperatives of a range of stakeholders, which necessitates decision-making about what texts are selected to achieve the goals for such a subject.

The Cox Report (Cox, 1989) established how English as a school subject comprises a mix of imperatives including: cultural heritage, personal growth, and cultural analysis, providing at least 
three frames with which to ask questions about which texts might serve these disparate purposes. The cultural heritage school of thought, often associated with the work of Matthew Arnold, places an emphasis on texts that 'reflect excellence', represent 'the best which has been thought and said' (Arnold, 1869), and traditionally manifest in an emphasis on canonical Western literature. The Personal Growth approach validates the idea that English should be tasked with supporting the individual to understand their own textual world, and that this can be achieved through a literary education that is diversified, including non-Western literary traditions (Dixon, 1975). This thinking includes moving from 'literature' to 'text' (Beavis, 1996) and expanding the work validated for study in the classroom, to include the written work of students (Britton, 1968, p. 9), as well as so-called high and low culture. Lastly, proponents of cultural analysis in education believe all texts to be equally worthy of study in so far as they are all elements of culture that warrant students' critical attention. Accepting that literature is both an ideology, and the means to express ideologies, be they nationalism, humanism, or other dominant values (Eagleton, 1983, p. 22), confers the need to analyse how all texts ideologically position us. This further necessitates the study of popular culture texts alongside the canon.

The twenty-first century's proliferation of New Media and digital texts has similarly created a need to ask what place these texts might have in the English curriculum. This has led to calls to expand English to include: videogames (Bacalja, 2018; Beavis, 1998), digital fiction (Allan, 2017), manga and anime (Cheung \& O'Sullivan, 2017) and digital video (Burn, 2003). However, the inclusion of popular culture texts into the English classroom has long been reported in the popular media as contentious and a threat to a rigorous literary education (McGraw, 2005), and the binary manner in which these debates are constructed, "Bart vs the Bard" (Misson, 1998, p. 85), has not abated over time.

Research on text-selection in Australia has tended to focus on explaining teachers' text selection decisions, including the role played by teachers' perception of their students' abilities (Teese, 2013), the selection of Australian literature as a way of claiming their "own national literary inheritance" (Doecke, Melean Davies, \& Mead, 2011, p. 1), the significance of students' engagement and context when selecting texts (Hastie \& Sharplin, 2012), access to resources to 
support teaching of texts (Mead, Kilner, \& Healy, 2010) and consideration of the 'closeness' and 'distance' of students to the texts selected (McLean Davies, 2012).

Research that focuses on the composition of compulsory text lists has been less common. Patterson's (2012) work identifying the 'Australianess' of text-lists across the Senior Victorian and New South Wales English Syllabi concluded that there was a strong presence of Australian literature, and that this could be explained by the goals articulated in curriculum documents regarding the appreciation and understanding of Australian society. Jogie's (2015a, 2015b) comparative analysis of texts selected for study across two education systems, the UK A-Levels and the Australian state of New South Wales' Senior English Curriculum, reported a disconnection between texts selected for study and a student population becoming increasingly diverse every year, with an overemphasis on well-known canonical texts, at the expense of contemporary texts that explore relevant issues for a diverse student population.

A range of views are present in Required Reading: Literature in Australian Senior Secondary English Since 1945 (Dolin, Jones, \& Dowsett, 2017), a collection of papers that utilize the ALIAS database (Analysis of Literature in Australian Schools), a collation of all texts found on prescribed reading lists for senior-secondary school curricula across Australian English and Literature courses since 1945. These papers demonstrate that the prevalence of canonical texts impacts on the symbolic range and representation of cultural identities available in the Australian classroom (Martin \& McLean Davies, 2017). A more recent analysis interested in the present of nonheteronormative representations of sexuality in texts appearing on the Australian Curriculum Senior Secondary English found a lack of diversity when it came to the presence of texts that include diverse sexual identities (McGraw \& van Leent, 2018).

Much has been written about the role played by pedagogy to enact the meaning of texts (Christie \& Misson, 1998; Eagleton, 1983). Teaching approaches have been shown to contribute to how the content of texts becomes realized in the context of English classrooms, including from movements associated with personal growth (Britton, 1970; Dixon, 1975), reader response (Rosenblatt, 1938, 1978), critical literacy (Freire, 1972), and literary critique (Leavis \& Thompson, 1933). These approaches allow educators to move beyond those representations and ideas 
contained within the pages of texts selected for study in classrooms. They combine with a multitude of socio-cultural contextual factors which frame the readings of the text, combining with relational processes to form 'literary praxis' (Van de Ven \& Doecke, 2011). However, the complex processes associated with meaning-making does not negate concerns about the nature of the texts found on compulsory curriculum lists, including their content and form.

Given the central role that texts play in mediating teaching and learning in the English classroom, there has been a lack of attention directed to quantifying the characteristics of text-lists utilised to teach the subject. This study seeks to address this gap in the field.

\section{Findings}

\section{Methodology}

This study examines the 360 texts which appeared on the Victorian senior English curriculum text-lists between 2010 and 2019. Texts were collated into a single data file and a coding frame was produced in order to analyse trends in text selection and the degree to which these trends reflect current policy objectives. We double-coded every text, using a content-analysis methodology, and employed coders (experienced English teachers and literary academics) who had read and viewed each text they coded. Every text was double-coded to improve the strength of the findings.

The coding frame was intended to identity a range of trends, from the year of publication, the sex of the author, the fictionality of stories, and characterisation. We focus our findings here on the following four trends:

- Text type: The coding team identified the genre of each text, using the six categories provided (novels, short stories, plays, films, poetry and other). The 'other' category was intended to capture any texts which did not fit in the other categories, but in practice was composed of non-fiction memoirs.

- Story setting (place and time): Coders classified the geographic setting of texts, recognising that many stories were located across multiple settings. Coders were also 
required to locate the plot within specific time periods. Again, coders could classify the text has occurring across more than one time period.

- Diversity (sex and Sexuality): coders were instructed to identify the sex of authors, using biological categories of male and female (there was no representation of transgender authors or directors in the text selection lists). Coders also identified the sex (male, female, non-aligned) and sexuality (heterosexual, non-heterosexual, not disclosed) of characters.

- Themes and affirmation: All texts were coded in terms of their exploration of themes, including: Indigeneity, religion, class and gender. Given the constraints/limitations of this paper, we limit our findings and analysis to data related to the coding of themes of indigeneity and colonisation.

\section{Text-type and fictionality}

The data revealed that texts which privilege the printed word dominate the text lists. Novels were the most frequent text, representing over one-third of all texts. This was followed by plays (16\%), films (16\%) and other (15\%). The least represented text types were poetry (8\%) and short stories (8\%). There were no digital texts in the sample, and no interactive texts.

Figure 1 Text types (\%) in the Victorian Senior English Curriculum text lists, 2010-2019 


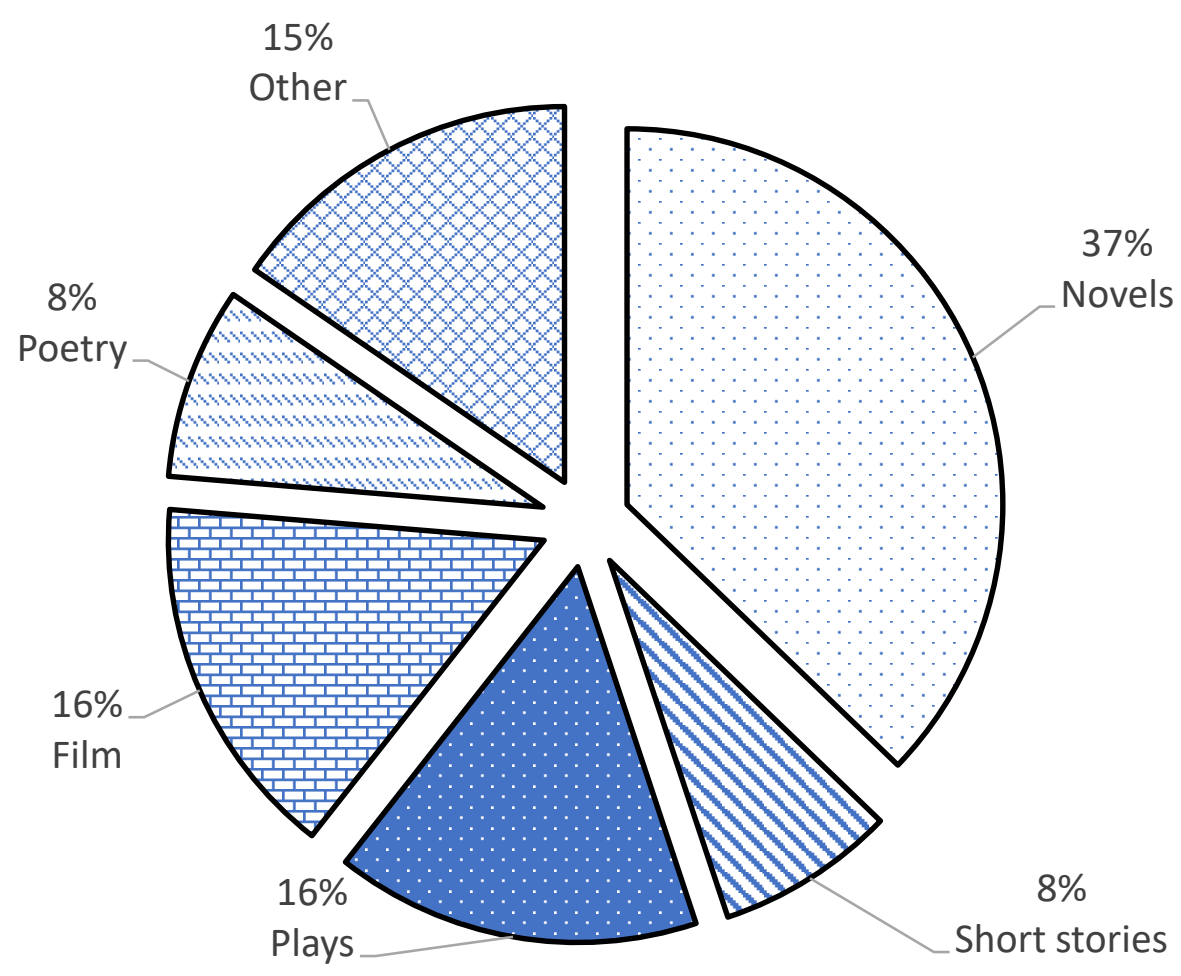

The 'other' category proved to be a proxy for memoirs, with all but two texts in this category representing historical or biographical accounts capturing the lives of individuals. The two exceptions were the texts 'Maus', by Art Spiegelman (1980), and 'Persepolis: The Story of a Childhood', by Marjane Satrapi, both graphic novels incorporating comic-style animations with extensive linguistic elements. Had memoirs been coded as novels, then this category would represent over half of all texts on these lists.

While the Australian Association for the Teaching of English calls for the study of language in "written, spoken and visual modes and through different types of texts, including: classic and popular texts, multimodal texts, fiction and non-fiction texts" (AATE, 2007, p. 15), the text-lists reveal that the printed word is clearly privileged, and the presence of multimodal texts reduced to a small number of films and the two aforementioned graphic comics. The lack of any digital texts is also of concern. At a time when the means of communicating stories has well and truly entered the digital realm, the absence of podcasts, computer games, interactive documentaries and other forms of social media narratives is inconsistent with the Study Design's claim that the curriculum should be taught through 'texts from the contemporary world'. 
Our study was also interested in the fictionality of texts on the lists, especially given the VCAA Guidelines explicit requirement that non-fiction texts be included on each year's list (Victorian Curriculum and Assessment Authority, 2018).

In our study, coders considered a work to be non-fiction (especially memoir) where the narrative and characters were represented to closely resemble the realities they referred to using ordinary prose (for example, Malala Yousafzai's I am Malala (1997) was non-fiction, whereas self-referential poetry, such as by Bruce Dawe's Sometimes Gladness (Dawe, 1978), was coded as fiction.)

Figure 2 Fiction and Non-fiction texts (n) appearing in the Senior Victorian English Curriculum text lists, 2010-2019

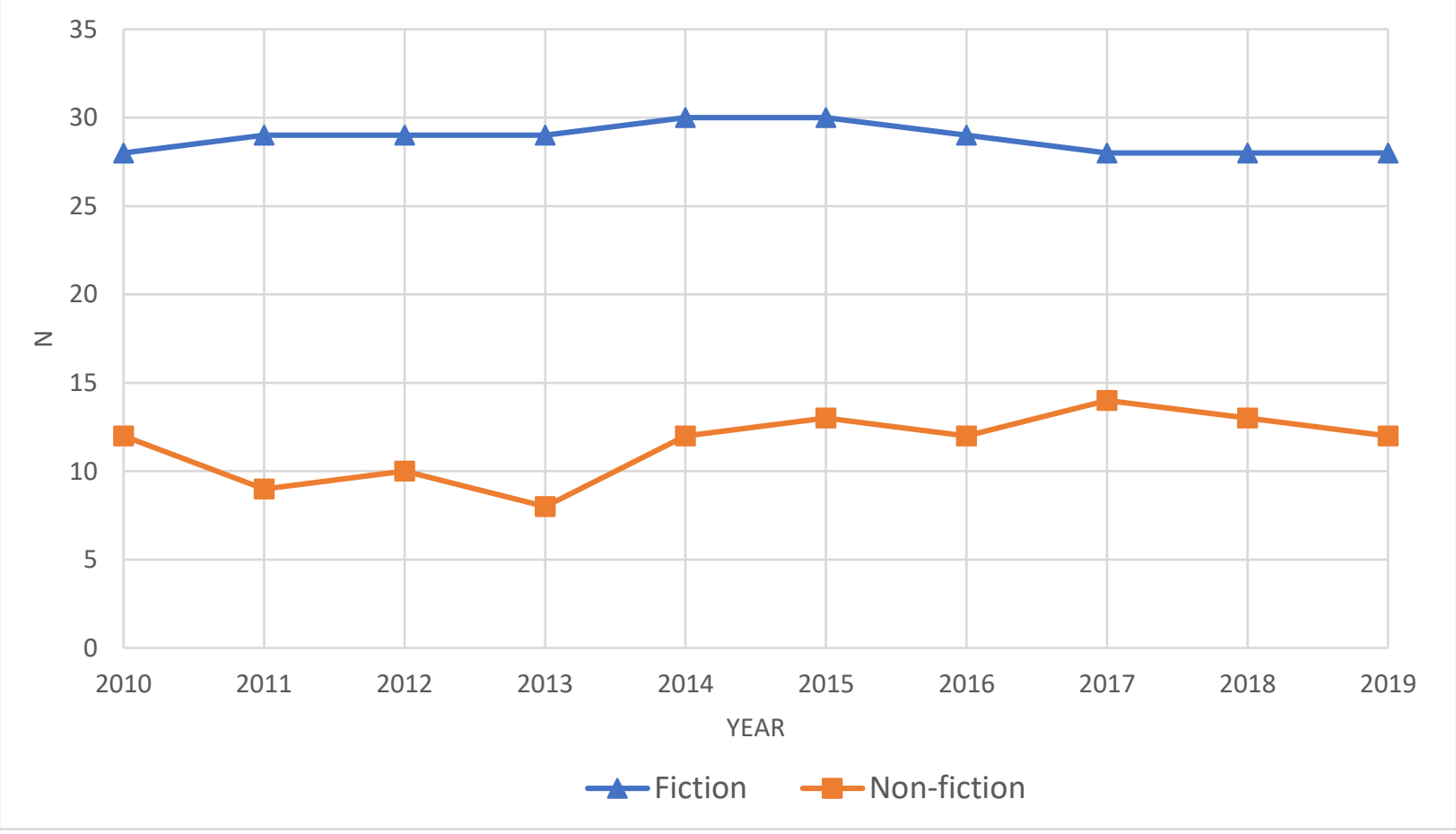

Memoirs and other non-fiction works have a clear place in VCE text lists. Over the ten-year sample, fiction represented over two-thirds of all texts listed. There is some variance in the number of non-fiction texts appearing each year, with an almost 90\% increase between 2013 and 2017. While policy documents informing the creating of these lists offer no justification for the value of non-fiction, their inclusion in numbers greater than required by the guidelines (Victorian Curriculum and Assessment Authority, 2018) suggests that they are perceived as offering examples of form, and the exploration of themes, worthy of 
study. This perception should be better justified in order to ensure 'memoir' is not over-represented in text selection lists.

\section{Story Setting - Place and Time}

Figure 3 The geographic setting of stories from texts (n) in the Senior Victorian English curriculum text lists, 2010-2019

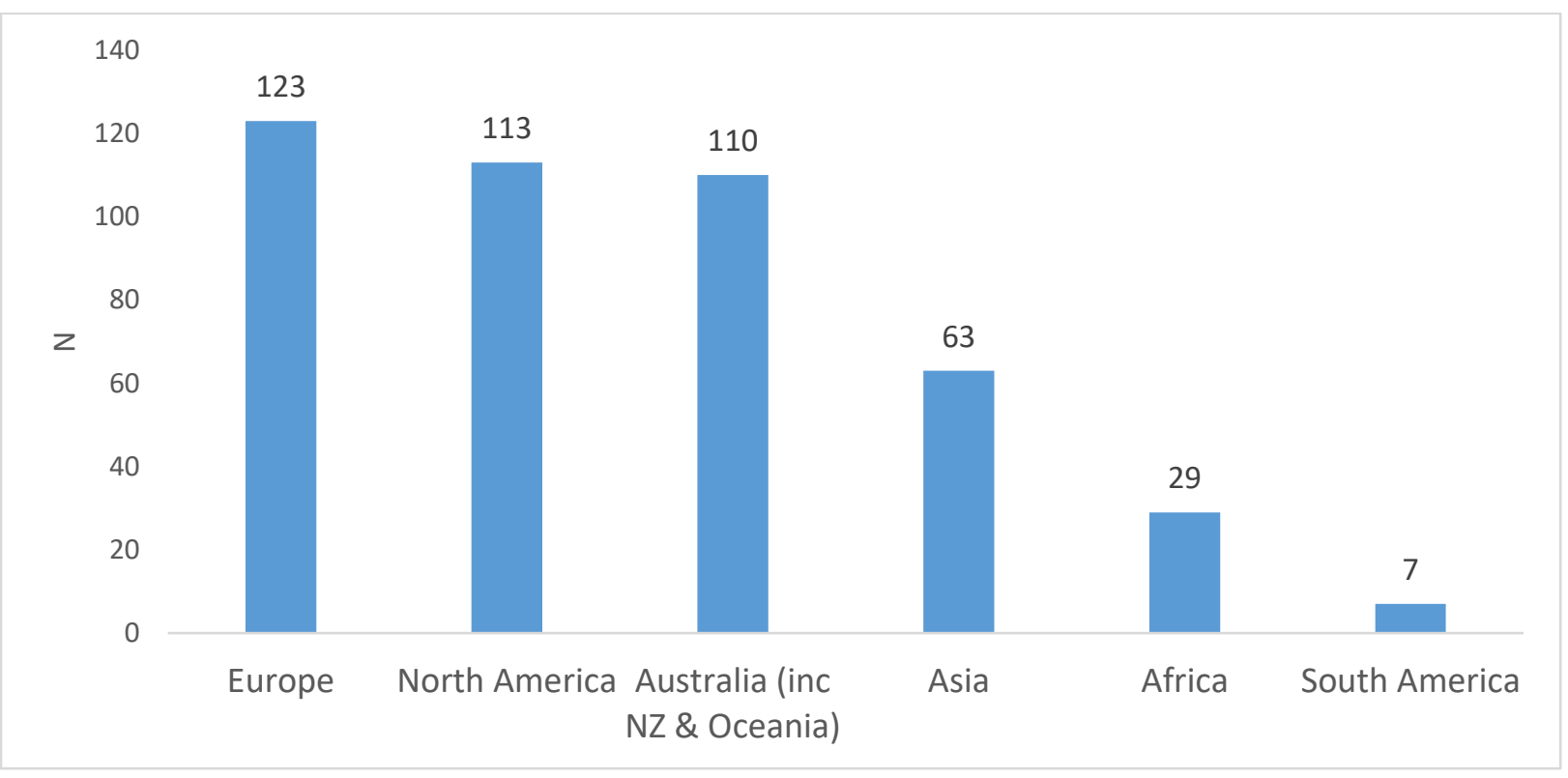

The data shows that the most popular geographic setting for texts was Europe, with 123 of the 360 texts including a substantial portion of the story within the continent. A closer look at these 123 texts reveals that the vast majority were set in the British Isles, likely reflecting the origins of the early colonial history of Australia as well as the British origins of many canonical works. This was followed by texts set in North America (113), with Australia (including New Zealand and Oceania) the third most popular setting to locate stories (110). As a percentage of all texts, this reveals that almost one-third of texts had a substantial portion of their story located in Australia.

Despite Australian Bureau of Statistics census data (2016) revealing that a majority of Australians born abroad are from Asia, and not Europe, less than one in five texts were located in Asia. This is particularly interesting given the Guidelines require that the text list reflect "engagement with Asia" (Victorian Curriculum and Assessment Authority, 2018, p. 7), and raises questions about which parts of Asia are represented (the Middle East, the Sub-continent, South East Asia), and how stories from these regions are used to 'engage' with peoples and cultures. Only 29 texts contained stories set in the African continent and just seven texts were set in the South American continent. 
In his discussion of the school-based canon, Ernie Tucker refers to popular authors from the British (Garner, Dahl, Lewis), American (Cormier, Paterson, Lee), and Australian (Marsden, Crew, Caswell) literary tradition to criticise the lack of adventurous selection (1998). What Figure 3 above reveals, is the marginalisation of stories from Asia, Africa and South America, and the privileging of the Western world. Given the Study Design's emphasis on the use of texts "from other cultures" in order to know their world and to participate in a global community, our study reveals there is a gap in student access to stories that explore peoples and cultures from a non-Western perspective.

Figure 4 The setting, time period, of stories from texts (n) in the Senior Victorian English curriculum text lists, 2010-2019

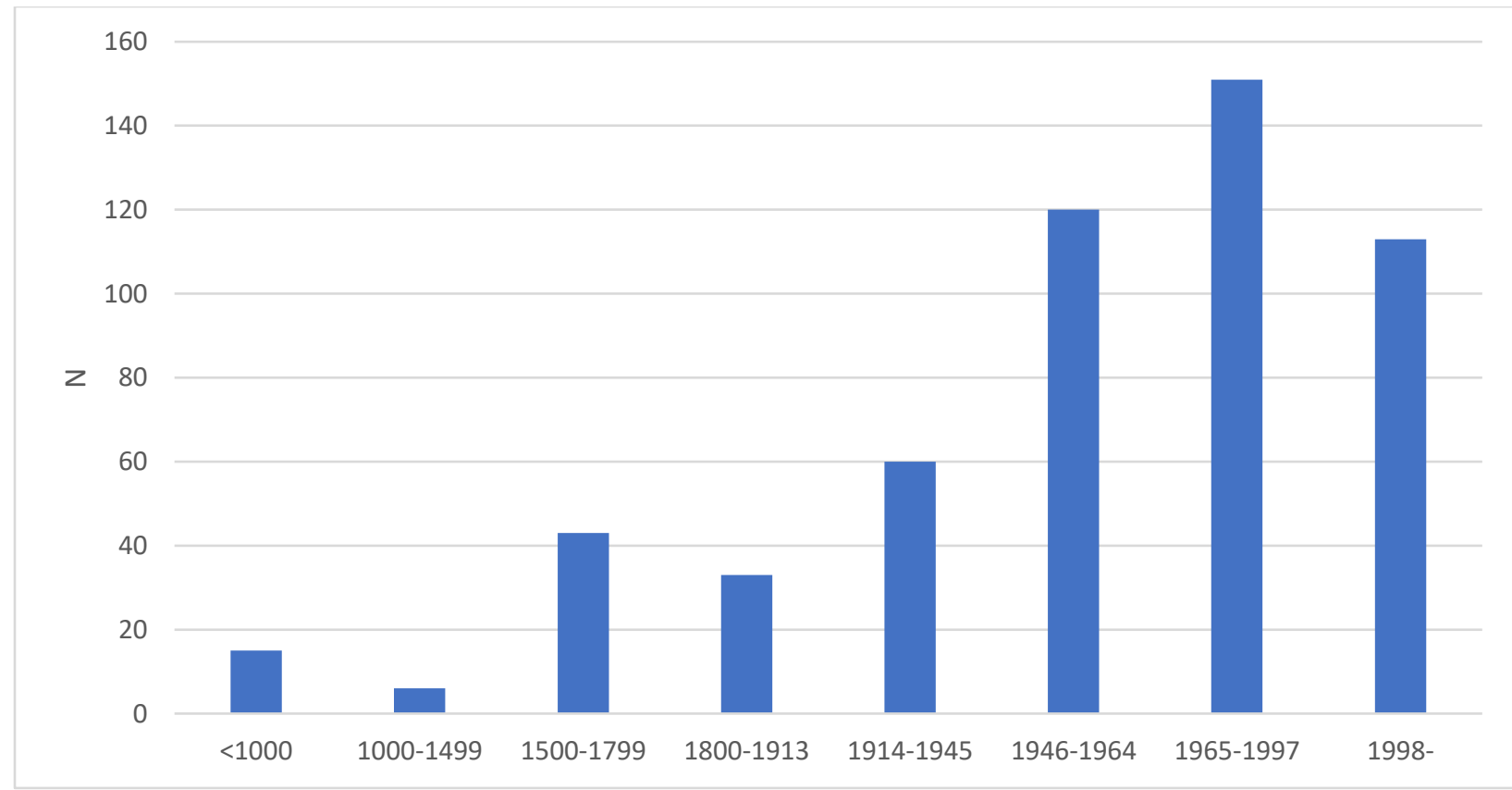

Figure 4 addresses the time period in which these stories were set. The vast majority of stories took place in the post-WW2 period. Over one-third of all texts were set between 1965-1997, closely followed by texts from 1946-1964 (the post war years). Thirty-one percent of texts were set in the time period 1998 to the present, the time period representing the lived era of most of the students studying texts from these lists. Texts set in this period were likely to represent a world somewhat familiar to students.

In contrast, less than $20 \%$ of texts were set in the pre- 1800 world. This might give the impression that the canon from that period has been neglected, an outcome that would justify perspectives that advocate for more texts from the 'Western cultural tradition' (Donnelly, 2010). It also appears to be fodder for those conservative commentators who argue that the absence of the West's 'great culture' in poorer schools 
allows those children to "rot in the pits of the dumbed down" (Bolt, 2009). However, a closer look at the text-lists reveals that almost $10 \%$ of all texts listed come from the writing of Shakespeare, Donne, Shelley, Dickens, Bronte, and Hemingway.

33 texts were located in the 1800-1913 period, with almost two-thirds of these located in Europe. Interestingly, despite the 19th and early 20th centuries representing times of expansive colonization throughout Africa, Asia, South America and Australia, very few texts contained stories set in that time period and in those geographic areas.

\section{Diversity - Sex and sexuality}

While creators of texts were overwhelmingly male (64\% to $36 \%$ overall) trends from 2010 until 2019, see Figure 5, showed increasing representation of female creators across all texts. Novels were almost exactly equal in representation ( $49.6 \%$ were authored by women); however, this was not the case for all text types. The figure for poems and films created by women was a mere $20 \%$. Importantly, the presence of female protagonists - defined in our study as a significant figure whose role is central to the narrative - increases across the period of study. While it is difficult to attribute this shift to any single factor, we infer one reason for this trend is changes in text selection practices by the panel, perhaps responding to increased public discourse and media recognition of the need for gender equality. However, this shift has not sought to address the marginalisation of homosexual protagonists within text lists and we would note that the presence of sex and sexuality within the classroom has always been controversial within public discourse (Robinson \& Davies, 2008).

One analysis of these trends would be to argue that the 'cultural heritage model' of texts, which the curriculum is built on, can also serve to reinforce inequalities as female authors and creators, like female protagonists, have been traditionally perceived and represented as 'universally' relevant but meaningful only in terms of gender and sexual difference (Pollock, 1999). A similar analysis has been made by scholars of sexuality (Butler, 1993). The 'cultural heritage model' is, however, indebted to notions of 'universality', which can be considered in relation to the idea that texts be "affirmative" and "constructive" in undefined senses in the curriculum guidelines (2017). The notion that literature can "speak to a common, shared humanity" (Felski, 2003, p. 14) can be questioned for its own relative inclusivity. Where VCAA guidelines state that texts that do deal with sex and sexuality must reflect "affirming, constructive exploration of related issues", 
this also suggests there is a dichotomy of a universal, shared sexual morality countered with a notion of sexual difference, and the presence of 'deviant' sexuality. Or, in other words, what writer Alice Pung calls "good literature versus 'bad morals"” (2017).

Figure 5 The sex of authors of texts ( $n$ ) from the Senior Victorian English curriculum text lists, 2010-2019

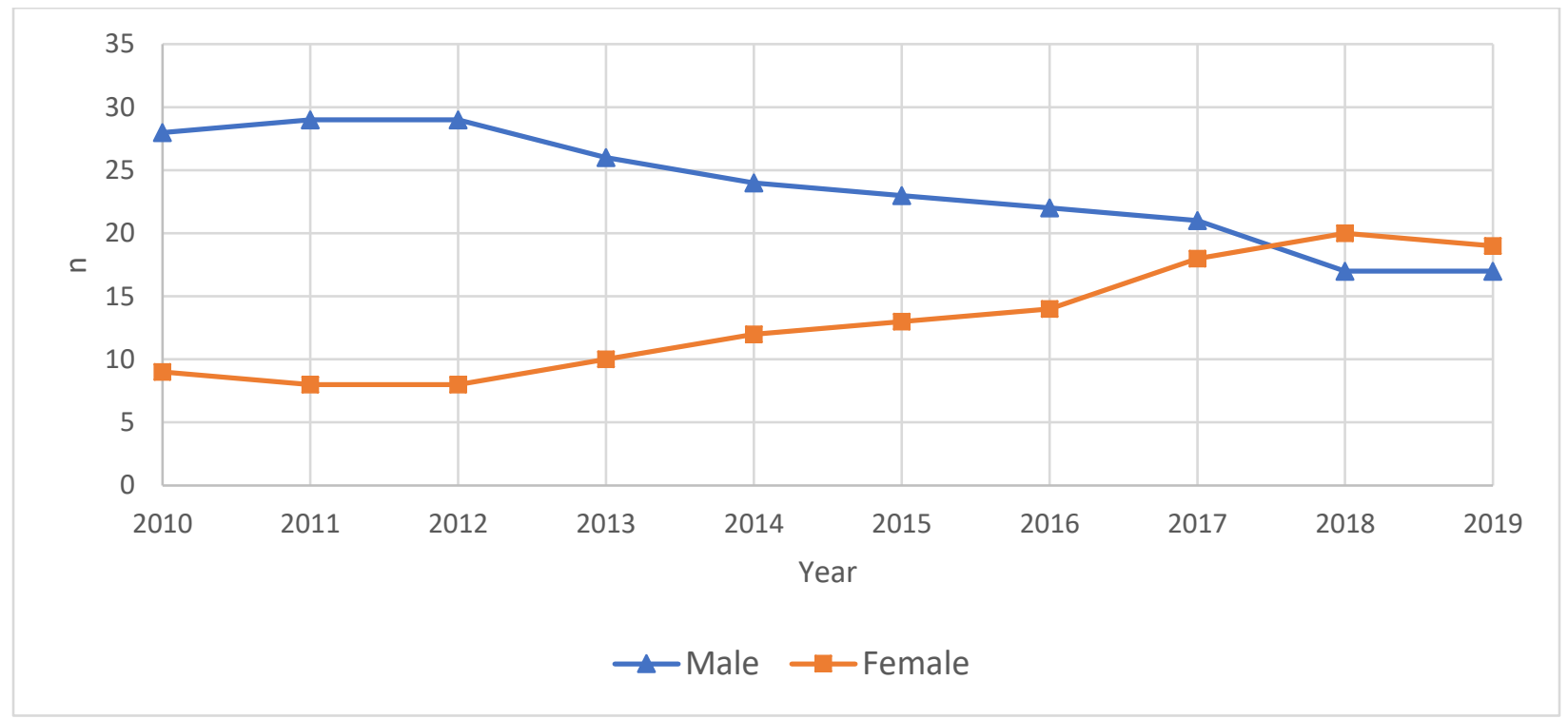

Figure 6 The sex of protagonists in texts $(n)$ from the Senior Victorian English curriculum text lists, 2010-2019

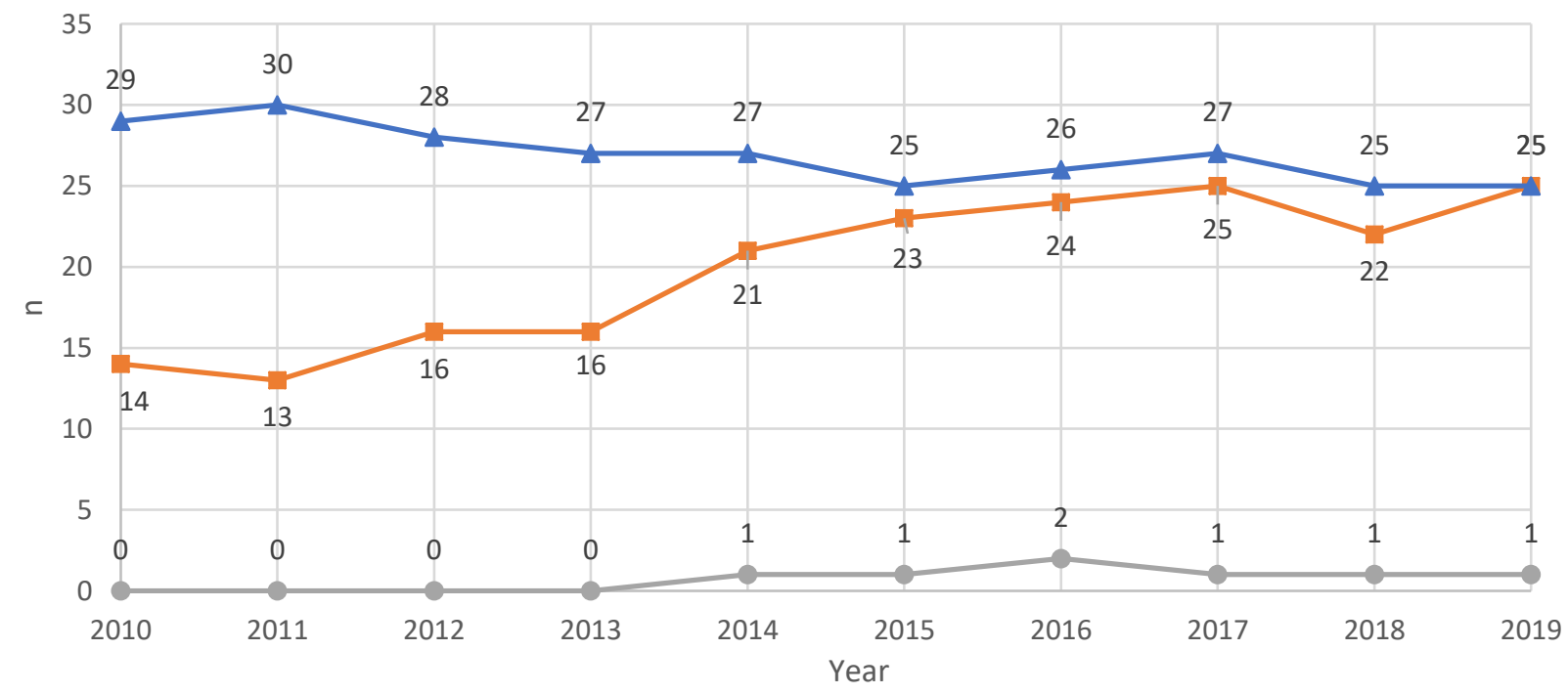

$\rightarrow$-Female $\rightarrow$ Male $\quad$ Non-aligned 
Figure 7 The sexuality of protagonists in texts $(n)$ from the Senior Victorian English curriculum text lists, 2010-2019

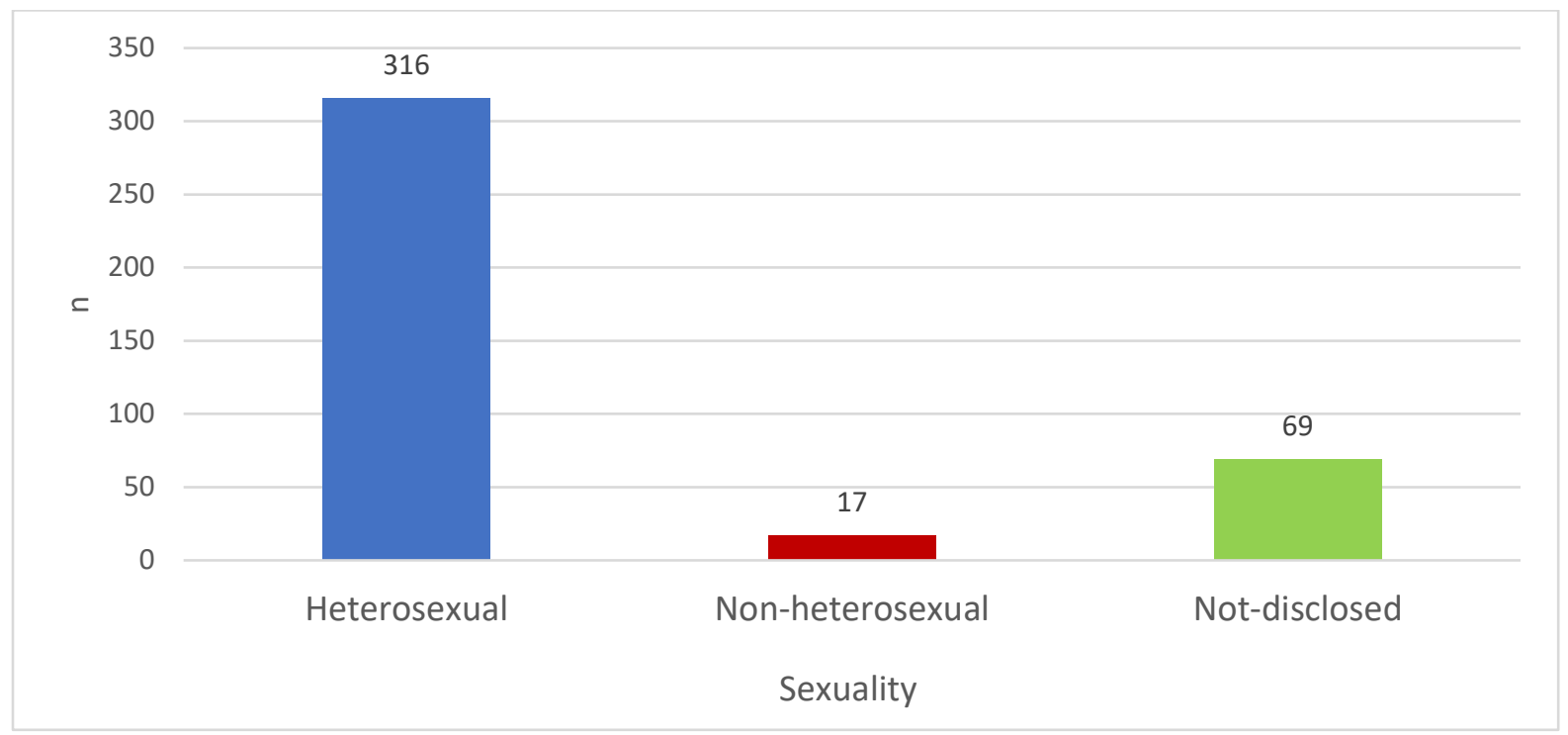

\section{Themes and Affirmation: Indigeneity and Colonisation}

Our findings showed that there was a distinct lack of Indigenous-authored novels and directors on text lists. The inclusion of Indigenous authors or directors was rare. Of the 360 included texts, there were only five specific works that were created by Australian Indigenous authors, directors and playwrights (poets were not represented). When we included for instances when these texts appeared multiple times in different years, our findings show that just $4 \%$ of all texts were by Indigenous creators. In addition, when films in this category are excluded, only 3 written texts remain. In total, written works by Australian Indigenous authors make up less than $2 \%$ of the total text-list, and there is only a single novel by an Australian Indigenous author. Of the 360 texts in our sample, only $3.6 \%$, or 13 texts, contained an Australian Indigenous protagonist.

Figure 8 The presence of an Indigenous protagonist (\%) in texts from the Senior Victorian English curriculum text lists, 2010-2019 


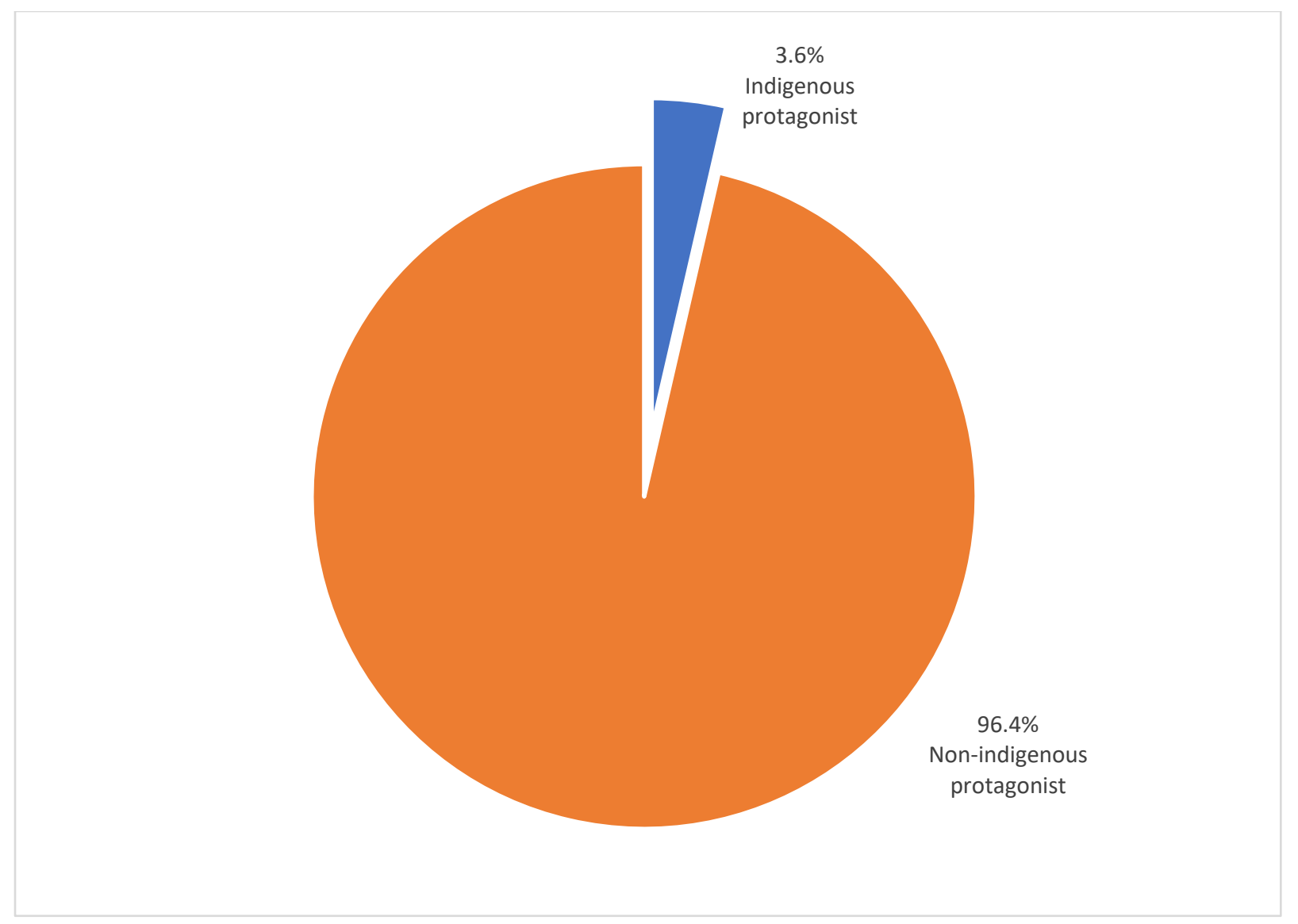

Figure 9 The exploration of themes of Indigeneity and settler colonisation (18\%) in texts from the Senior Victorian English curriculum text lists, 2010-2019 


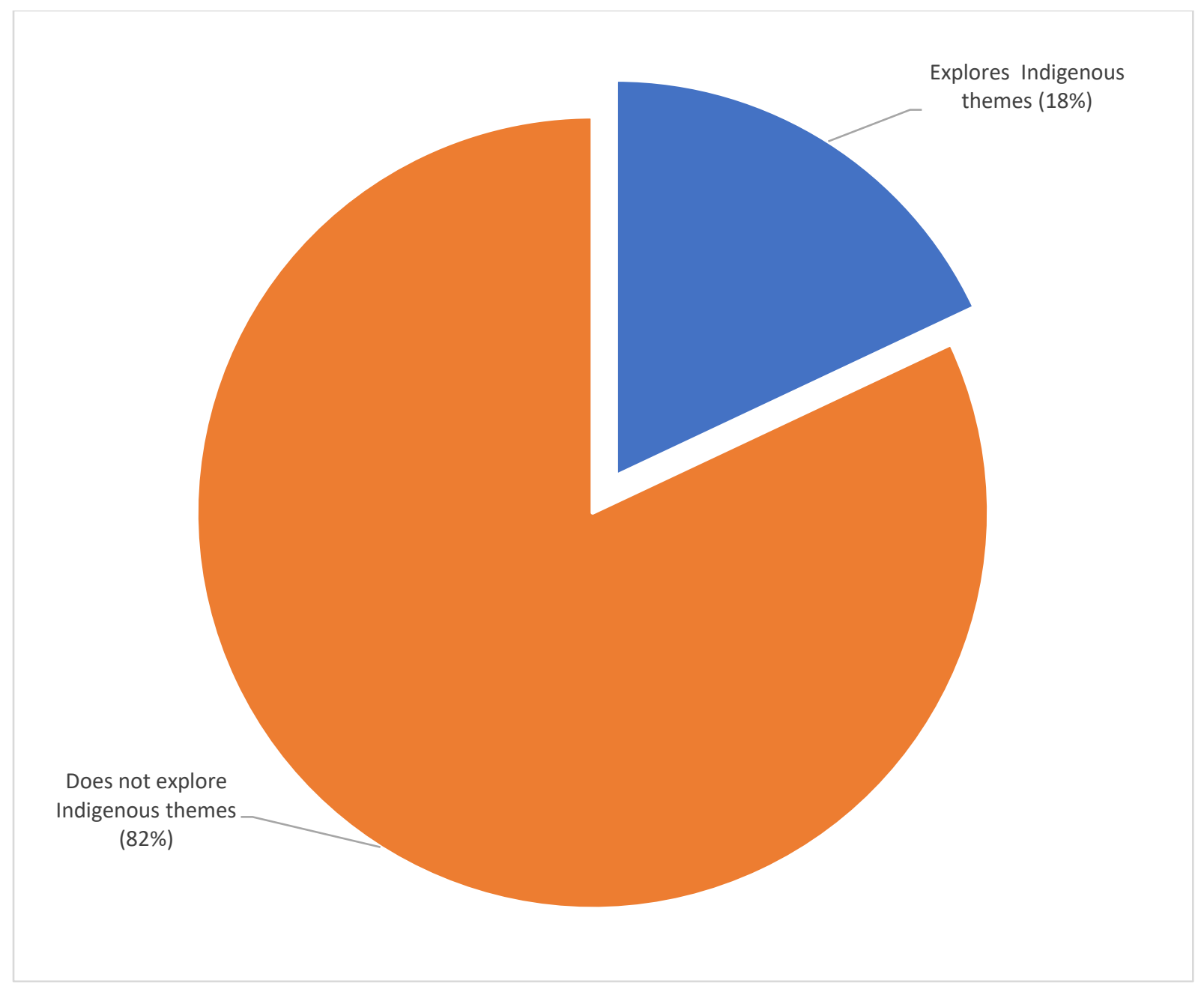

In contrast, however, we found, that $58 \%$ of all texts set in Australia explored themes of colonisation and Indigeneity. The gap between the high presence of themes about Indigeneity in Australian texts and low representation of Indigenous authors and Indigenous protagonists can be linked to arguments about the 'colonial world view'. We have analysed these trends and texts elsewhere (Bacalja \& Bliss, 2019), and agree with the position espoused by thinkers such as Marcia Langton (1993) and Jeanine Leane (2010) that canonical Australian literature and the school curriculum have the power to reinforce and reproduce the dichotomy of powerful vs powerless, which extends back to the beginning of colonisation. This is especially the case where texts, authored by non-Indigenous Australians, contain tokenistic Indigenous characters, or 'symbolic' figures that play little active role in the narrative. Our findings are clear in this regard: 
the majority of works on the list represent themes of colonisation but do not contain significant Indigenous characters. The vast majority of texts explore relevant themes from a non-Indigenous character's perspective and are the work of non-Indigenous creators. As expressed by Leane: "I am not suggesting that this work and others like it be scrapped - they are important texts that reveal synchronic slices of settler consciousness of and about Aboriginal people at any given time. But I am challenging the notion that these are Aboriginal stories. They are not" (2016, p. 42). In this respect, Indigenous authorship and characterisation should be considered - alongside the presence of themes - in future text selection practices if policy aims for inclusion are to be realised.

When we look at just those texts which are set in Australia and explore Indigenous themes we find that very few of these are set in the early invasion, colonisation and settler period. Less than $15 \%$ of texts which explored Indigenous themes were set between 1788-1913. In contrast, texts that explore these themes were far more likely to be located in $20^{\text {th }}$ and $21^{\text {st }}$ century contexts. Contradictions between VCAA's adherence to principles of inclusivity and for the need for diverse points of view in relation to cultural and political issues, with the hegemonic reality of the curriculum are brought to light here. We argue that the mere presence of themes about colonisation and Indigeneity is not enough, especially given the documented history of the objectification of Indigenous peoples by non-Indigenous Australians, from a literary point of view, from the late $18^{\text {th }}$ century onward until present day (Moreton-Robinson, 2004; Nakata, 1995). The Australian landscape, Australian history and identity are historically contested spaces and as Leane suggests - these contestations should be represented and explored to realise principles of inclusivity. Against benign notions of "affirmative" and "constructive" texts, there is clear demand and need for stronger presence of Indigenous voices in curriculum lists if policy values are to be realised. 


\section{Conclusion}

The project aimed to investigate text-list trends in the VCE English curriculum between 2010 and 2019 and the degree to which these lists reflected the imperatives outlined in guiding policy documents. We found that some trends reflected curriculum priorities. The inclusion of a range of written texts is consistent with the curriculum's aim for students to engage with a diversity of styles and genres. This is represented by the inclusion of novels, short stories, film, poetry and plays. Likewise, with non-fiction works comprising almost $30 \%$ of all texts, the lists adhere to the VCAA Guidelines regarding fictionality. The text-lists included texts set in a range of geographic settings, with all continents represented. Finally, the trend towards a balance of stories with male and female protagonists is positive, and reflects the guidelines' goals to achieve a balance in representation.

The aims from policies that are not met encompass a range of issues. First, there is a lack of multimodality and diversity in text type. With a small percentage of films and a single graphic novel across the ten year span, we also found that memoirs were over-represented in the category that counted non-traditional text types. Second, there is a lack of texts set in nonWestern settings with the Anglophone world predominating. The policy aim for inclusivity, especially with respect to Asian literature, is not being met. Third, there is a lack of representation of diverse sexualities and, fourthly, few female poets, directors and playwrights. Moreover, policy guidelines on inclusivity with respect to sex and sexuality remain vague and unclear. Finally, there is an over-representation of texts that represent themes about Indigeneity and colonisation, but an under-representation of texts created by Indigenous Australians. This conforms to the notion of the 'colonial gaze'; inclusive authorship should be considered more seriously in text selection.

In particular, we found the vague language in policy, centred on notions of affirmative and constructive narratives, and the need for 'inclusivity', requires a more robust and rigorous definition in policy to guide text selection practice. While, in principle, we do not disagree with these words in their intention, they remain overly benign and somewhat obscure when examined in light of trends that show exclusion of a range of text-types, narrow representations of sexuality and the problematic exploration of Indigenous themes. 
We suggest the following recommendations for educators seeking to enact the principles found in policy documents associated with these text-lists. These suggest we need:

1. A greater range of text-types, including multimodal and digital texts.

2. More stories set in contexts from outside the Western world, including across the AsiaPacific region.

3. The representation of characters which represent a diversity of sexualities.

4. A careful consideration of the sex of authors, playwrights, directors and poets, especially across the text types.

5. More texts created by Indigenous Australians.

We see these lists, and the trends captured above, as historical products, a consequence of ways of thinking about literature and subject-English that are simultaneously inclusive and exclusive. They are products of immense negotiation, primarily by those who are empowered to make decisions about what counts as texts worthy of study in our classrooms. As such, they reflect the dispositions of text-selection panel members, curriculum officers and those curriculum board members who hold ultimate authority over the composition of each year's list. They are examples of structures within school systems that contribute to the reproduction of the distribution of cultural capital (Bourdieu \& Passeron, 1990) and which have the capacity to open windows to worlds unfamiliar to our students, to places, peoples and perspectives that they may never otherwise know. And, while this paper does not seek to minimise the powerful role played by pedagogy to support students to understand the worlding inside and outside of these texts, it does make the case for thinking more critically about text-selection decision-making.

As Misson states, “the world isn't a world of single truths, any more than it's a world in which there is one set of values that allows you to reject some texts and elevate others (2006, p. 16)." If students are to take from their schooling the capacity to deal with the diversity of the texts they come across and the diversity of the world they live in, then teachers will need to be able to select from text-lists that are truly reflective of values of diversity, multiculturalism and inclusivity. 


\section{References}

AATE. (2007). AATE Statements of Belief. English in Australia, 42(2), 13-16.

ACARA. (2019). Cross-curriculum priorities: The Australian Curriculum.

Allan, C. (2017). Digital fiction: 'Unruly object' or literary artefact? English in Australia, 52(2), 21-27.

Apple, M. W. (1979). Ideology and Curriculum. Boston: Routledge and Kegan Paul.

Apple, M. W. (1982). Education and Power. Boston: Routledge and Kegan Paul.

Arnold, M. (1869). Culture and Anarchy. An Essay in Political and Social Criticism. London: Thomas Nelson and Sons.

Austin, A. G., \& Selleck, R. J. W. (1975). The Australian Government School 1830-1914: select documents with commentary. Carlton, Vic: Pitman Publishing.

Bacalja, A. (2018). What critical literacy has to offer the study of video games. Australian Journal of Language and Literacy, 3(41), 144-154.

Bacalja, A., \& Bliss, L. (2019). Representing Australian Indigenous Voices: Text Selection in the Senior English Curriculum. English in Australia, 54(1), 43-52.

Beavis, C. (1996). Changing constructions: Literature,'text' and English teaching in Victoria. In B. Green \& C. Beavis (Eds.), Teaching the English subjects: Essays on English curriculum history and Australian schooling (pp. 15-35).

Beavis, C. (1998). Pressing (the right?) buttons: literacy and technology, crisis and continuity. English in Australia, 123, 42-51.

Bolt, A. (2009, May 29, 2009). Kids should not be dumbed down, says Andrew Bolt. The Herald Sun. Retrieved from https://www.heraldsun.com.au/news/opinion/kids-should-not-be-dumbeddown-says-andrew-bolt/newsstory/8e386ef0688a7dc8b531aa080d28ff21?sv=ab0306179ef0e42208a976e8dd6347cb

Bourdieu, P., \& Passeron, J.-C. (1990). Reproduction in education, society, and culture (1990 ed.). London ; Newbury Park, Calif.: Sage in association with Theory, Culture \& Society, Dept. of Administrative and Social Studies, Teesside Polytechnic.

Britton, J. (1968). Response to literature. In J. R. Squire (Ed.), Response to literature (pp. 3-10). Champaign, Illinois: National Council of Teachers of English.

Britton, J. (1970). Language and Learning. London: Allen Lane The Penguin Press.

Burn, A. (2003). Poets, skaters and avatars: performance, identity and new media. English Teaching: Practice and Critique, 2(2), 6-21.

Butler, J. (1993). Bodies that Matter: On the Discursive Limits of Sex. London: Routledge.

Cheung, K., \& O'Sullivan, K.-A. (2017). 'Big fans', 'Experts', and those 'In need of a challenge': Teacher attitudes to'manga and anime kids' in the Secondary English classroom. English in Australia, 52(2), 28.

Christie, F., \& Misson, R. (1998). Literacy and schooling. London ; New York: Routledge.

Clark, A. (2008). History's children : history wars in the classroom. Sydney, N.S.W.: University of New South Wales Press.

Cox, B. (1989). English for ages 5-16 [The Cox Report]. London: DES.

Dawe, B. (1978). Sometimes gladness : collected poems, 1954-1978. Hawthorn, Vic: Longman Cheshire.

Devine, M. (2005, 11/8/2005). Why art is a dirty word. Sydney Morning Herald.

Dixon, J. (1975). Growth through English : set in the perspective of the seventies. London: Oxford University Press for the National Association for the Teaching of English.

Doecke, B., MeLean Davies, L., \& Mead, P. (Eds.). (2011). Teaching Australian Literature: From Classroom Conversations to National Imaginings: Wakefield Press.

Dolin, T., Jones, J., \& Dowsett, P. (2017). Required Reading: Literature in Australian Senior Secondary English Since 1945: Monash University Publishing. 
Donnelly, K. (2010). The ideology of the national English curriculum. Quadrant, 54(5), 26.

Donnelly, K. (2018). Our 21st century tragedy - how the west was lost.

Eagleton, T. (1983). Literary Theory: An Introduction. Oxford: Blackwell.

Enright, A. (2017). Diary. Retrieved from https://www.Irb.co.uk/v39/n18/anne-enright/diary

Felski, R. (2003). Literature after feminism: University of Chicago Press.

Freire, P. (1972). Pedagogy of the oppressed. Harmondsworth, Middlesex: Penguin.

Green, B., \& Beavis, C. (1996). Teaching the English subjects: essays on English curriculum history and Australian schooling. Geelong, Vic: Deakin University Press.

Hastie, M., \& Sharplin, E. (2012). Why did you choose that text?: Influences on English teachers' choices of reading materials for students. English in Australia, 47(2), 36-44.

Jogie, M. R. (2015a). Desperate shadows of 'Belonging': Revealing pedagogical issues with teaching prescribed English texts in the NSW Higher School Certificate (HSC). The Australian Educational Researcher, 42(3), 335-352.

Jogie, M. R. (2015b). Too pale and stale: prescribed texts used for teaching culturally diverse students in Australia and England. Oxford Review of Education, 41(3), 287-309.

Langton, M. (1993). Well, I heard it on the radio and I saw it on the television...: An essay for the Australian Film Commission on the politics and aesthetics of filmmaking by and about Aboriginal people and things. North Sydney, NSW: Australian Film Commission.

Leane, J. (2010). The whiteman's Aborigine.

Leane, J. (2016). Other Peoples' Stories. Overland, 225, 41-45.

Leavis, F. R., \& Thompson, D. (1933). Culture and environment: The training of critical awareness: Chatto $\&$ Windus.

Martin, S. K., \& McLean Davies, L. (2017). What the Dickens?: Exploring the role of canonical texs in mediating subject English in Australia. In T. Dolin, J. Jones, \& P. Dowsett (Eds.), Required Reading: Literature in Australian Schools Since 1945 (pp. 238-260). Clayton, Victoria: Monash University Press.

MCEETYA. (2008). Melbourne Declaration on Educational Goals for Young Australians. Retrieved from Melbourne:

McGraw, K. (2005). HSC English in the media: The reporting of conventions and controversies. English in Australia(143), 27-35.

McGraw, K., \& van Leent, L. (2018). Textual constraints: Queering the senior english text list in the Australian curriculum. English in Australia, 53(2), 28-39.

McLean Davies, L. (2012). Auditing subject English: A review of text selection practices inspired by the National Year of Reading. English in Australia, 47(2), 11-17.

Mead, P., Kilner, K., \& Healy, A. M. (2010). Teaching Australian literature survey: final report: May 2010. Retrieved from https://www.austlit.edu.au/austlit/page/6129914:

Misson, R. (1998). Questioning Popular Culture. In W. Sawyer, K. Watson, \& E. Gold (Eds.), Re-Viewing English (pp. 85-89). Sydney: St Clair Press.

Misson, R. (2006). Connecting with the World of Texts. Idiom, 42.

Moreton-Robinson, A. (2004). Whiteness, epistemology and Indigenous representation. Whitening race: Essays in social and cultural criticism, 1, 75-88.

Nakata, M. (1995). Culture in education: A political strategy for us or for them? Ngoonjook(11), 40-61.

Patterson, A. (2012). Australian literature: Culture, identity and English teaching. Journal of the Association for the Study of Australian Literature, 12(1), 1-17.

Pearson, P. D. (2004). The reading wars. Educational policy, 18(1), 216-252.

Pollock, G. (1999). Differencing the canon: Feminism and the writing of art's histories. London, UK: Routledge. 
Pung, A. (2017). Don't say teenagers aren't ready for dark fiction. With the right teacher, it can change lives Retrieved from https://www.theguardian.com/books/2017/oct/02/dont-say-teenagersarent-ready-for-dark-fiction-with-the-right-teacher-it-can-change-lives

Robinson, K., \& Davies, C. (2008). Docile bodies and heteronormative moral subjects: Constructing the child and sexual knowledge in schooling. Sexuality \& Culture, 12(4), 221-239.

Rosenblatt, L. M. (1938). Literature as exploration. New York: Noble and Noble Publishers Inc.

Rosenblatt, L. M. (1978). The reader, the text, the poem. Carbondale, IL: Southern Illinois University Press.

Snyder, I. (2008). The literacy wars : why teaching children to read and write is a battleground in Australia. Crows Nest, N.S.W.: Allen \& Unwin.

Spiegelman, A. (1980). Maus: a survivor's tale. New York: Pantheon Books.

Teese, R. (2013). Academic success and social power: Examinations and inequality. Melbourne: Melbourne University.

Tucker, E. (1998). Wide Reading. In W. Sawyer, K. Watson, \& E. Gold (Eds.), Re-Viewing English (pp. 174181). Sydney, NSW: St Clair Press.

Van de Ven, P.-H., \& Doecke, B. (Eds.). (2011). Literary praxis: A conversational inquiry into the teaching of literature. Rotterdam, Boston: SensePublishers.

Victorian Curriculum and Assessment Authority. (2015). Victorian Certificate of Education English and English as an Additional Language Study Design. In. https://www.vcaa.vic.edu.au/Documents/vce/english/EnglishEAL-SD-2016.pdf.

Victorian Curriculum and Assessment Authority. (2018). VCAA principles, guidelines and procedures for prescribed VCE text lists.

Williams, R. (1961). The long revolution: An analysis of the democratic, industrial, and cultural changes transforming our society. New York: Columbia UP.

Yousafzai, M. (1997). I am Malala : the girl who stood up for education and was shot by the Taliban. New York, NY: Little, Brown, and Company. 


\section{University Library}

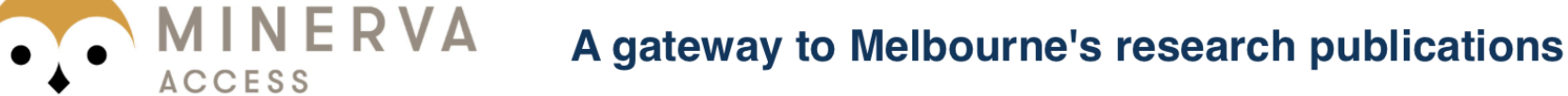

Minerva Access is the Institutional Repository of The University of Melbourne

Author/s:

Bliss, L;Bacalja, A

Title:

What counts? Inclusion and diversity in the senior English curriculum

Date:

2020-03-14

Citation:

Bliss, L. \& Bacalja, A. (2020). What counts? Inclusion and diversity in the senior English curriculum. The Australian Educational Researcher, 48 (1), https://doi.org/10.1007/ s13384-020-00384-X.

Persistent Link:

http://hdl.handle.net/11343/254625 